\title{
Development and Application of Nonsense Syllable Repetition Test for Evaluating Phonological Retrieval and Sequencing Abilities
}

\author{
Eun Joo Ryu ${ }^{a}$, Ji-Wan $\mathrm{Ha}^{\mathrm{b}}$ \\ aDepartment of Speech-Language Pathology, Graduate School of Rehabilitation, Daegu University, Gyeongsan, Korea \\ ${ }^{b}$ Department of Speech-Language Pathology, Daegu University, Gyeongsan, Korea
}

Correspondence: Ji-Wan $\mathrm{Ha}$, $\mathrm{PhD}$

Department of Speech-Language Pathology,

Daegu University, 201 Daegudae-ro, Jillyang-eup,

Gyeongsan 38453, Korea

Tel: $+82-53-850-4327$

Fax: $+82-53-850-4329$

E-mail: jw-ha@daegu.ac.kr

Received: October 8, 2018

Revised: November 15, 2018

Accepted: November 30, 2018

This work was supported by the National Research Foundation of Korea Grant Funded by the Korean Government (No. NRF-2017R1C1B1010913).
Objectives: The purpose of this study is to develop a nonsense Syllable Repetition Test (nSRT) with validity and reliability, and to verify its usefulness. This study also intended to establish a scoring system that classifies and evaluates the retrieval ability and the sequencing ability of subjects. Methods: The final items were derived by exploratory factor analysis. A Cronbach's alpha internal consistency analysis and word similarity survey were conducted, and average syllable frequency was calculated on nSRT items. Then, four, five, and six year old children were examined using the nSRT, and the differences in their performance were analyzed according to phonological processing types (phonological retrieval and phonological sequencing) and number of syllables of items. Results: The final items consisted of seven words in each of the 3,4 , and 5 nonsense syllables groups. The internal consistency of all items was very high $(=.914)$, and all items showed low word similarity and high mean syllable frequency. As the children's age increased, their test performance improved significantly; and the higher the number of syllables, the more difficult the test was. This study also found that among the phonological processing tasks, it was significantly more difficult to sequence items than to retrieve items. Conclusion: This study is significant in that it develops a new nSRT with validity and reliability and establishes the retrieval and sequencing score system.

Keywords: Nonsense Syllable Repetition Test, Phonological retrieval ability, Phonological sequencing ability, Validity, Reliability
언어를 습득하는 시기에 아동이 제일 먼저 하게 되는 일은 청각 적으로 들려오는 무의미한 소리조합을 받아들이는 것이다. 처음에 는 그저 비단어일 뿐이었던 이 무의미한 소리조합은 반복적 입력과 그것에 해당하는 의미와의 반복적 연결을 통해 비로소 아동의 머 릿속에 단어로 자리 잡게 된다. 돌 무렵 말소리산출에 요구되는 조 음운동능력이 어느 정도 성숙해지면, 아동은 처음 듣는 소리자극 도 곧잘 따라한다. 소리자극의 입력, 그리고 그것의 즉각적 따라하 기 과정을 통해 비단어는 이전보다 훨씬 더 효율적으로 단어로 자 리 잡는다. 따라함으로써 소리 정보를 한 번 더 입력하고, 소리 내어 되뇌임으로써 음운 정보와 조음운동 정보를 효과적으로 기억하
고, 그러는 동안 해당 의미를 반복적으로 떠올림으로써 의미 정보 도 견고해질 수 있다. 입력된 청각 정보를 언어 정보로 처리하는 이 와 같은 과정을 통해 아동은 점차적으로 어휘 수를 늘려가고 성공 적인 의사소통자로 거듭나게 된다.

아동이 언어를 배울 때 처음 접하는 소리자극을 의미도 모른 채 따라하는 이러한 활동은 최근 의사소통장애 분야에서 활발히 연 구되고 있는 비단어 따라말하기 과제에서 대상자에게 요구되는 능 력과 매우 흡사하다. 즉, 언어습득 초기에 주변에서 우연적으로 듣 게 되는 익숙하지 않은 말소리 자극을 받아들이고 기억하고 따라 하는 과정은 검사 상황에서 검사자가 들려주는 비단어 자극을 듣 
고 기억해서 그대로 따라말해야 하는 활동과 닮아있다. 그렇기 때 문에 전자에 어려움이 있었던 의사소통장애 아동은 이후 후자의 상황에서도 어려움을 보일 수 있다. 따라서 의사소통장애 아동이 비단어 따라말하기 검사에서 결함을 보인다는 연구결과들(Baddeley, Gathercole, \& Papago, 1998; Dollaghan \& Campbell, 1998; Jung \& Ha, 2017; Kang \& Kang, 2016; Kim \& Ha, 2014; Ryu \& Ha, 2016)은 당연한 것이다. 더 나아가 비단어 따라말하기 과제는 의사 소통장애의 선별에 매우 민감한 검사방법으로 그 중요성이 부각되 기도 하였다(Boerma et al., 2015). 더욱이 비단어 따라말하기는 연 령에 상관없이 아동부터 노인 대상자까지 광범위하게 적용될 수 있 고, 또한 특정 언어에 국한된 것이 아니기 때문에 다문화권 대상자 또는 외국인의 의사소통장애나 언어학습능력을 진단하는 데에도 매우 유용하다(Campbell, Dollaghan, Needleman, \& Janosky, 1997).

이처럼 비단어 따라말하기가 시공간을 초월한 보편적인 의사소 통장애 선별 검사도구로 부각되는 첫 번째 이유는 이것이 단어가 아닌 ‘비단어’ 과제이기 때문이다. 비단어이기 때문에 학습한 적이 없고 이전에 들어본 경험조차 없으므로 전 연령층에서 의사소통 장애인을 선별하는 데에 유용하고, 비단어이기 때문에 언어에 영 향을 받지 않으므로 언어 보편적일 수 있다. 따라서 비단어 따라말 하기는 그 과제가 ‘비단어', 즉 의미를 가지고 있지 않은 말소리 조합 으로 이루어졌다는 점에 가장 큰 중점을 두어야 할 것이다. 그런데 이러한 비단어의 의미성 여부는 경우에 따라 달라질 수 있다. 예를 들어 /동가파/라는 자극어는 아동에게는 아무런 의미가 없는 비단 어이지만, 어른의 경우 이 말소리 조합에서 '돈 갚아'라는 의미를 떠 올린다면 이것은 더 이상 비단어가 아니다. 따라서 대상자의 어휘 및 언어지식은 비단어 따라말하기 과제에 절대적인 영향을 미친다. 그뿐만 아니라 비단어 자극어가 기존 단어와 얼마나 닮았는지도 비단어 따라말하기의 수행에 영향을 미친다. 단어와 유사한 비단 어는 대상자로 하여금 해당 단어를 떠올려 과제를 성공적으로 수 행하도록 하는 하향적 처리과정(top-down approach)을 발휘하게 하고(Lee, Ha, Koo, Hwang, \& Pyun, 2016), 더 나아가 어휘량이 풍 부한 대상자는 그렇지 않은 대상자에 비해 이러한 하향적 처리과 정을 보다 효율적으로 사용한다(Lee et al., 2016). 때문에 비단어 항 목은 그 자체로 비단어일 뿐만 아니라 단어유사성이 낮은 비단어 여야 한다(Lee et al., 2016). 또한 Dollaghan과 Campbell (1998)은 비단어 따라말하기 과제 수행이 대상자의 어휘지식에 영향을 받지 않기 위해서는, 비단어를 구성하는 모든 일음절들이 해당 언어에 존재하는 단어여서는 안 된다는 점을 강조하였다.

비단어 따라말하기 과제의 중요성이 부각되는 두 번째 이유는 언어 유전과 관련이 있기 때문이다. 이미 여러 유전 연구에서도 설
명된 바 있듯, 비단어 따라말하기의 결함은 유전적 소인을 가진 언 어장애, 읽기장애, 말소리장애 등 다양한 의사소통장애 아동의 핵 심 특성으로 보고되었다(Adams \& Gathercole, 2000; Bishop, 2002; Bishop, Adams, \& Norbury, 2004; Shriberg, Lewis, Tomblin, et al., 2005). Bishop (2002)은 의사소통장애로 진단받은 아동뿐 아니라 의사소통장애 위험이 있는 아동, 그리고 의사소통 문제를 더 이상 보이지 않지만 이전에 의사소통장애 병력이 있었던 아동까지도 비 단어 따라말하기 과제에서 공통적으로 결함을 보인다고 하였다. 이는 의사소통장애의 잠재성, 즉 유전적 소인과 비단어 따라말하 기 결함을 연관 짓는 근거이기도 하다. 이때 비단어 따라말하기가 특정 의사소통장애가 아니라 전 영역의 의사소통장애를 광범위하 게 선별하고 이와 관련된 유전적 소인을 밝히는 데에 기여할 수 있 는 이유 중 하나로, 이 과제가 인지-언어-말 처리의 다양한 단계들 을 아우르고 있기 때문임을 들 수 있다(Shiriberg et al., 2009). 비단 어 따라말하기는 들려주는 자극을 수동적으로 반복하는 단순한 과제로 생각될 수 있지만, 과제를 정확하게 수행하기 위해서는 처 음 접하는 음향학적 입력신호를 지각하고, 이것을 음운적으로 재 인한 후, 일련의 음운정보들을 표상화하여 일정 시간 동안 보유하 고, 그 표상과 일치하는 음운출력 처리과정을 통해, 최종적으로 말 운동 프로그래밍과 실행 과정까지 성공적으로 거쳐야 한다. 이처럼 여러 단계들을 거치기 때문에 비단어 따라말하기는 의사소통장애 와 관련 있는 다양한 기저요인들을 모두 포함한다. 그뿐만 아니라 비단어 따라말하기 과제를 이용한 여러 연구들은 그 결과를 대상 자의 음운단기기억 또는 음운작업기억 등 음운처리능력과 연관 지 어 해석하기도 한다. 의사소통장애 분야도 마찬가지이며, 언어장 애, 말소리장애, 읽기장애 등의 기저요인으로 음운처리능력의 결함 을 지목한 많은 연구들이 그것을 입증하기 위해 비단어 따라말하 기 과제를 이용하였다. 최근 국내에서 진행된 비단어 따라말하기 관련 연구를 살펴보면, Oh와 Yim (2013)은 2-3세의 말늦은 아동과 정상아동에 대해 2-6음절 비단어 따라말하기 수행 능력을 분석한 결과, 음절길이가 증가할수록 음운 기억 용량, 청각적 기억, 음운 조 합 등의 영향으로 비단어 따라말하기 과제 수행 능력이 저조하게 나타났다고 설명하였다. Lee와 $\operatorname{Sim}$ (2003)은 4세 단순조음장애 아 동 15 명과 정상아동 15 명을 대상으로 음절길이 효과 및 말소리유 사성 효과 유무에 대해 살펴보았다. 그 결과, 단순조음장애 아동의 경우 2,3 음절과 같은 짧은 음절길이에서도 정상아동과 차이를 보 이는 등 모든 음절길이에서 낮은 음운기억 수행을 보였고, 말소리 유사성 효과는 나타나지 않았다. 이는 곧 단순 조음음운의 문제도 음운기억 수행에 영향을 준다는 것을 시사한다고 설명하였다. 이 와 같이 비단어 따라말하기 과제의 경우 말-언어 처리는 물론 음운 
처리능력까지, 모든 영역을 아우르는 검사라고 할 수 있다. 그러나 비단어 따라말하기 과제에서 가장 중요한 비단어를 구성할 때에는 앞서 선행연구를 통해 설명한 바와 같이 일음절에서부터 존재하는 단어여서는 안 된다. 그럼에도 불구하고 우리말의 경우 일음절 한 자어의 비중이 높아 무의미한 일음절들로만 비단어를 구성하기는 쉽지 않다. 이런 이유 때문인지 국내에서 제작된 비단어 따라말하 기 과제들은 단어유사성이 낮은 항목에서조차도 각 일음절들의 무 의미성은 고려하고 있지 않다는 제한점이 있다.

다양한 인지-언어-말 처리과정 중 특히 음운처리와 관련된 연구 에 비단어 따라말하기 과제가 집중적으로 활용되고 있는 만큼, 비 단어 따라말하기 과제는 대상자의 음운처리능력을 보다 다차원적 으로 분석할 수 있는 심층적인 검사여야 할 것이다. 음운정보처리 는 단순히 하나의 정보만 처리하는 것으로 그치지 않는다. 대개의 경우 일련의 음운정보들이 연속적으로 입력되고 또한 일련의 음운 정보들을 연속적으로 출력해야 한다. 일련의 음운정보들을 처리할 때에는 음소 자체의 정보뿐 아니라 음소 간 순차적인 순서 정보까 지 다루어야 한다. 즉, 각 음소들이 일단 선택되고, 이후 선택된 음 소들은 첫 음소부터 다음 음소 순서로 순차적으로 적절한 위치에 배열되어야 한다(Hwang, 2018). 배열 단계에서 어려움을 보일 경우 말소리 오류가 초래될 수 있고, 이러한 말소리 오류는 말소리장애 집단에서 특히 더 잘 관찰될 수 있다. 이와 관련하여 Hwang과 $\mathrm{Ha}$ (2010)는 음운부호화 과제에서 인출 방해자극과 배열 방해자극에 따른 일반아동과 말소리장애 아동의 음운부호화 수행력을 비교하 였다. 그 결과, 말소리장애 아동은 일반아동에 비해 배열 방해자극 에 영향을 많이 받았다. 즉, 음운부호화 과정 중 배열 단계에서 문 제를 보이는 것으로 해석할 수 있다. 말소리장애 집단뿐만 아니라 자연스러운 노화로 인해 음운처리능력이 저하되는 노년층 또한 청 년층에 비해 순차적 순서로 음소를 배열하는 데 어려움을 보이거 나(MacKay \& James, 2004), 음소배열 단계에서 어휘편향화의 영 향을 많이 받는다(Kim \& Ha, 2018). 따라서 음운처리는 음소의 인 출 처리와 동시에 음소 간 배열 처리까지를 모두 의미하며, 이러한 이유로 음운처리능력을 타당하게 평가하기 위해서는 음소 인출 능 력뿐 아니라 음소들의 배열 능력까지 다루어야 할 것이다. 그러나 비단어 따라말하기를 이용하여 대상자의 음운처리능력을 살펴본 그 수많은 연구들(Lee \& Sim, 2003; Hwang \& Ha, 2018; Oh \& Yim, 2013; Jung \& Ha, 2017) 가운데, 국내에서는 음소 배열에 대한 것을 다룬 연구는 찾아보기 어렵다.

따라서 본 연구의 목적은 기존 비단어 따라말하기의 이러한 제 한점들을 보완하여 음운처리능력을 평가하기에 보다 타당한 새로 운 비단어 따라말하기의 과제를 개발하는 것이다. 본 연구에서 개
발하고자 하는 비단어 따라말하기 과제의 가장 큰 두 가지 특징은 다음과 같다. 첫째, 어휘지식의 영향을 최대한 통제한 비단어들로 과제 항목을 구성하고자 하였다. 그러기 위해서는 비단어를 구성 하는 각각의 음절 자체도 의미가 없는 일음절이어야한다(Dollaghan \& Campbell, 1998). 그 이유는, 예를 들어 비단어 '발타감'의 경우 아무런 의미가 없는 소리 조합, 즉 비단어이지만, 이 자극어를 듣게 되면 대상자들은 첫 번째 음절에서는 '발(신체부분), '발(가리개)' 등을, 두 번째 음절에서는 ‘타다', ‘타오르다, '불, '말’ 등을, 세 번째 음절에서는 '감(과일)', '가다' 등을 떠올릴 수 있기 때문이다. 다시 말해 대상자들은 자극어를 듣자마자 각 음절로부터 의미적으로 관련 있는 어휘정보들을 활성화시키게 된다. 따라서 비단어 내 모 든 음절로부터 어휘 또는 의미의 활성화 가능성을 최소화하여야 하며, 본 연구자들은 이러한 비단어 항목을 제작하고자 노력하였 다. 둘째, 음운처리능력을 타당하게 평가하기 위해 음소 인출 능력 과 음소들의 배열 능력을 모두 평가할 수 있는 검사를 개발하고자 하였다. 인출과 배열의 두 가지 능력을 모두 평가하는 데에 기존 비 단어 따라말하기 검사에서 주로 사용되었던 정·오반응 채점, 음소 단위 채점, 음절단위 채점으로는 제한점이 많았다. 기존의 채점 방 법들은 단지 인출만을 다루고 있어 배열 능력을 평가하는 것은 불 가능하였다. 따라서 본 연구에서는 인출과 배열을 독립적으로 평 가할 수 있는 채점 방법을 고안하였다. 이에 대해서는 연구방법 부 분에 자세히 기술되어 있다.

이상과 같이 살펴보았듯이 본 과제는 무의미 일음절들로 이루어 진 비단어에 대해 그것을 구성하는 음소들을 얼마나 많이, 또 얼마 나 정확한 순서대로 기억하는지를 평가하는 것이다. 이는 기존의 비단어 따라하기 과제와 다소 차별적인 것으로, 새로운 자극어와 분석방법을 제안하고 있다. 따라서 과제 성격이 보다 명확하게 드러 나도록, ‘비단어' 대신 ‘무의미 음절'이라는 용어를 사용하여 ‘무의 미 음절 따라말하기 검사(nonsense Syllable Repetition Test, nSRT)' 로 명명함으로써, 본 과제를 기존 비단어 따라말하기 검사와 구별 하고자 한다. 본 연구에서는 nSRT를 개발한 후 과제 항목들의 타 당도와 신뢰도를 검증할 것이다. 그리고 개발된 nSRT를 일반아동 들에게 실시하여 연령 집단 간 인출 수행력과 배열 수행력이 자극 어의 음절수가 길어짐에 따라 어떠한 차이를 나타내는지 비교하고 자 한다. 이를 위해 'nSRT의 개발'과 'nSRT의 적용'을 실험 1 과 2 로 구분하여 원고를 기술하였다. 실험 1에서는 타당성과 신뢰성을 갖 춘 nSRT의 최종 항목이 어떻게 구성되었는지, 실험 2에서는 연령 집단 간 음절수와 음운처리 종류에 따라 $\mathrm{nSRT}$ 의 수행력에 차이가 있는지를 살펴볼 것이다. 


\section{연구방법}

\section{실험 1: nSRT의 개발}

예비 항목 선정

검사 제작 시 기본적인 원칙은 무의미 일음절들로 구성된 비단 어 항목을 제작하는 것이다. 이를 위해 그 자체로는 의미가 없어 어 휘저장소에 단어로 저장되어 있지 않은 일음절들을 추린 후 그 일 음절들을 조합하여 자극어를 만들었다. 우선 한국어 표준발음법 에서 허용하는 자음 19 개, 단모음 10 개, 이중모음 11 개를 모든 경우 의 수로 조합하여 $\mathrm{CV}$ 또는 $\mathrm{CVC}$ 음절구조의 일음절들을 만들었 다. 한국어의 경우 종성에 겹자음을 허용하므로, 종성에는 19 개의 자음을 조합하여 표기 가능한 겹자음 형태도 모두 반영하였다. 비 단어 따라말하기가 말소리로 실시되는 검사임에도 불구하고 자소 (grapheme)의 조합으로 자극어 제작을 시작한 이유는, 참고한 사 용빈도 문헌들이 모두 문어 기반일 뿐 아니라 해당 일음절이 의미 를 포함하고 있는지 여부를 보다 효율적으로 파악하기 위함이었다. 이와 같은 과정을 통해 총 11,172 개의 일음절이 추출되었다. 이후 다음의 기준을 적용하여 적절하지 않은 일음절들을 순차적으로 제외하였다.

첫째, Kim과 Kang (1997)의 말뭉치 연구를 참고하여 한국어에 존재하지 않는 ‘비사용 음절'을 8,867개를 제외하였다. 둘째, Jo (2002) 의 단음절 명사 표제어에 근거하여 의미가 존재하는 동음이의어 일음절 단어 224 개와 비동음이의어 일음절 단어 310 개를 제외하 였다. 셋째, 첫 번째와 두 번째 절차를 통해 추려진 1,771 개의 음절 가운데 한글사전을 참고하여 동사, 관형사, 형용사, 부사로 홀로 의 미 있게 사용되는 일음절어를 제외하고, 추가적으로 '뻬', '헤', '푸' 와 같이 그 자체로는 의미가 없으나 말소리로 지각하였을 때 '빼다', '하다', '해', '푸우' 등의 의미가 떠오를 수 있는 일음절을 제외하였 다. 대명사, 수사, 감탄사, 조사로서의 의미까지 제한하면 남은 일음 절이 거의 없어 이는 허용하였다. 이와 같은 절차를 통해 총 219 개 의 일음절이 추출되었다. 이후 이 일음절들을 자음군 단순화, 평폐 쇄음화 등을 적용하여 철자 표기가 아닌 말소리 표기로 전환하였 다. 넷째, 본 검사가 대상자의 조음능력까지 아우르는 검사임은 부 정할 수 없으나 최대한 음운처리능력에 초점을 두기 위해, 조음기 능의 미성숙으로 인해 어린 아동들이 보편적으로 산출에 어려움 을 보이는 치경마찰음 / ㅅ/, / 씨와 유음/리를 포함한 일음절을 제 외하였다. 다섯째, 본 검사가 대상자의 말소리 지각능력까지 아우르 는 검사라는 것 또한 부정할 수 없으나 마찬가지로 최대한 음운처 리능력에 초점을 두기 위해, 소리 변별 또는 확인에 어려움이 있는 이중모음과 / 기/, / 기/가 포함된 일음절을 제외하였고, 모음 / / / 와
/ 게/는 / 게/로 일원화하여 표기하였다. 따라서 모든 일음절은 7 개의 단모음으로 이루어졌다. 여섯째, 종성, 특히 어중종성이 있을 경우 청지각적 어려움으로 인해 초래될 오류의 가능성을 배제할 수 없 으므로 최종적으로 $\mathrm{CVC}$ 구조의 일음절도 제외하였다. 이상과 같 은 일련의 절차를 거쳐 최종적으로 추출된 일음절은 총 35 개였다.

4 음절 비단어부터 의사소통장애 아동과 일반아동 간, 그리고 연 령에 따라 따라말하기 수행 차이가 두드러진다는 선행연구들(Lee, 2010; Paik \& Hwang, 2011; Hwang, 2015; Hwang \& Ha, 2010)을 참 고하여, 기준 음절수인 4음절과 그와 인접한 음절수인 3음절, 5 음 절로 구성된 비단어를 제작하였다. 이를 위해 35 개의 일음절에 대 해 난수표를 생성한 후 반복적으로 무선조합을 실시하여, 3음절, 4 음절, 5 음절 음절조합을 각각 21 개, 17 개, 15 개씩 만들었다. 53 개 의 음절조합에 대해 언어치료학과 학부생 60 명을 대상으로 Likert 5 점 척도 평점법 $(1=$ '단어와 매우 유사하지 않음, $2=$ "단어와 유사 하지 않음, $3=$ "보통임', $4=$ =단어와 유사함', $5=$ '단어와 매우 유사 함')의 단어유사성 조사를 실시하였다. 그 결과에 근거하여 단어유 사성이 평균 2점 이하에 해당하는 비단어만을 남기고 나머지는 제 외하여, 최종적으로 3 음절 13 개, 4 음절 12 개, 5 음절 10 개의 비단어 가 추출되었다. 이상과 같이 추출된 35 개의 비단어를 예비 항목으 로 하였고, 이것을 Text to Speech (TTS) 프로그램을 이용하여 소리 자극으로 녹음하였다.

\section{채점 방법 확립}

인출 점수는 선행연구에 근거하여 $(\mathrm{Kim} \& \mathrm{Ha}, 2014)$ 정확하게 인 출한 자음과 모음에 대해 각 1 점씩 부여한 후, 전체 음소에 대한 인 출 음소의 백분율로 구하였다. 이때 주의할 점은 인출 수행력의 경 우 해당 음소가 정확한 위치에서 산출되었는지 여부는 고려하지 않는다는 것이다. 즉, 비단어 자극어에 포함된 음소가 어떤 위치에 서든 인출되기만 하면 위치에 상관없이 모두 점수화된다. 예를 들 어 비단어 '즈두버히꼬'를 [두지버부오]라고 산출한 경우 두 번째 음절의 '두를 첫 음절에서 산출하고 첫 음절 '즈'의 /ㅈ/를 두 번째 음절의 초성에서 산출하였지만, [ᄃ], [下], [지 음소 자체는 인출을 하였기 때문에 인출 점수로 계산된다. 결과적으로 [두지버부오]는 인출된 음소 [ㄷ], [ㅈ], [ㅂ], [-T], [ ] ], [-1], [ㄱ]에 대해 각 1점씩 채점 되어 총 7점이 된다. 어린 아동일수록 생략이 빈번하여 축약된 형태 로 반응을 보이거나(예: [즈더히꼬]), 동일한 음소를 반복하는 경우 가 종종 관찰된다(예: [드두더히꼬]). 이때 위치가 어긋나 해당 음소 가 다른 모음 또는 자음과 결합되었더라도 자극어에 포함된 음소 가 존재하면 모두 점수화하고, 동일 음소를 중복 채점하지 않도록 주의해야 한다. 비단어 항목은 $\mathrm{CV}$ 음절구조들의 조합으로 이루어 
졌기 때문에, 자극어에 대해 모든 음소를 인출하면 3음절은 6점(2 점 $\times 3), 4$ 음절은 8 점 $(2$ 점 $\times 4), 5$ 음절은 10 점 $(2$ 점 $\times 5)$ 이 된다.

기존 비단어 따라말하기 과제에서 배열 수행력을 점수화한 선행 연구는 전혀 찾아볼 수 없었다. 배열을 점수화할 때 가장 문제가 되 는 점은 배열의 시작 기준점을 어디로 봐야 할지에 대한 것이었다. 첫 음소를 기준점으로 하여 순차적으로 이후 음소들을 배열한다 고 가정하면, 앞에서 예로 들었던 [즈더히꼬]와 같이 생략이 포함된 반응에서 [-1], [ㅎ], [ I], [ᄁ]], [ㄱ]는 반응어의 기준점인 첫 음소 [ㅈ] 로부터 4 번째에서 8 번째까지 위치한다. 반면 자극어 '즈두버히 꼬'의 첫 음소 [지를 기준점으로 하면 해당 음소들은 6 번째에서 10 번째까지에 해당한다. 때문에 [즈더히꼬] 반응의 [-1], [ㅎ], [ I], [ㄲ], [ㄱ] 는 자극어와 위치가 모두 일치하지 않아 배열 점수를 전혀 받 을 수 없다. 그러나 검사자들은 직관적으로 생략된 음운들을 제외 한 후 나머지 음운들 내에서 [-1], [ㅎ], [ ] ], [T], [ㄱ] 를 배열화한 능 력을 긍정적으로 평가하고자 할 것이다. 이러한 문제점을 해결하기 위해 비단어의 첫 음소(시작점)와 마지막 음소(끝점), 두 지점을 배 열의 기준점으로 삼기로 하였다. 이것은 알파벳 순서 기억하기 과제 에서 알파벳 자극들을 배열하는 능력을 점수화한 선행연구(Fischer-Baum \& McCloskey, 2015)의 채점 방법을 참고한 것이다. 이는 인간의 정상적인 기억처리 특성인 초두효과(primary effect)와 최 신효과(recency effect), 즉 일련의 정보들 가운데 제일 처음과 제일 마지막(최근)에 입력된 것이 정보 보유에 중요한 역할을 한다는 이 론에 바탕을 두고 있다. Gupta (2005)와 Gupta, Lipinski, Abbs와 Lin (2005)은 비단어 따라말하기에서 초두효과와 최신효과를 입 증한 바 있고, 이 연구들을 근거로 본 연구의 배열 점수에 시작점과 끝점 기준을 적용하였다.

구체적인 채점 방법은 다음과 같다. 첫 음소(시작점)와 마지막 음 소(끝점)를 각각 기준점으로 하여, 산출된 비단어의 음소들이 제시 된 비단어와 동일한 순서에 위치할 경우 순차적으로 각 1 점씩 부여 받는다. 따라서 배열 점수는 시작점 기준과 끝점 기준의 두 측면에 서 각각 점수화되고, 이 점수들을 합산하여 최종 배열 점수를 얻게 된다. 예를 들어 '즈두버히꼬'를 [즈더히꼬] 라고 한 경우 시작점 기 준에서 해당 음소가 동일한 위치에 배열된 것, 즉 첫 번째, 두 번째, 세 번째에 위치한 [ㅈ], [-], [ᄃ]에 각각 1점씩, 3점을 받고, 끝점 기 준에서 거꾸로 첫 번째, 두 번째, 세 번째, 네 번째, 다섯 번째에 위치 한 [ㄱ], []], [l], [ㅎ], [기가 각각 1점씩, 5점을 받아, 총 배열 점수 는 3점과 5점을 합산한 8 점이 된다. 배열 점수 채점 시 주의할 점은 정확하게 인출은 되었으나 시작점과 끝점의 기준에서 순차적인 위 치가 어긋나는 음소는 점수를 획득할 수 없다는 것이다. '즈두버히 꼬'에 대해 [두지버부오]라고 반응한 경우 시작점 기준에서 해당 음
소가 동일한 위치에 배열된 것, 즉 다섯 번째, 여섯 번째의 [ㅂ] , [-1] 에 1점씩, 끝점 기준에서 첫 번째에 위치한 [ㄱ] 에 1점을 부여하여 배열 점수는 총 3점이다. 그 외 [ᄃ], [-]], [ㅈ], [ []는 인출은 되었으 나, 시작점과 끝점 모두에서 순차적인 순서로 배열되지 않아 배열 점수는 획득할 수 없다. 또한 [ㅂ], [-1]의 경우 시작점 기준에서는 해 당 음소의 위치가 자극어와 동일하기 때문에 점수를 획득할 수 있 었으나, 끝점에는 마지막 음절의 초성이 생략되어 위치가 달라졌기 때문에 점수를 받을 수 없다. 이러한 방식으로 계산되는 배열 점수 의 만점은 3 음절은 12 점(시작점 기준 6점+끝점 기준 6점), 4 음절 16 점(시작점 기준 8 점+끝점 기준 8 점), 5 음절 20점(시작점 기준 10 점+ 끝점 기준 10 점)이 된다. 배열 점수 또한 인출 점수와 마찬가지로 최 종적으로 전체 배열 점수에 대한 획득 배열 점수의 백분율로 변환 된다.

인출과 배열 점수 채점 시 왜곡 오류는 정반응으로 간주한다. 이 는 비단어 따라말하기 검사의 일차적 목적이 조음운동능력의 평 가보다는 음운의 인출과 배열 능력, 즉 음운처리능력의 평가에 초 점을 둔 것이기 때문이다.

\section{최종 항목 도출}

예비 항목에 대해 타당도와 신뢰도 검증 절차를 거쳐 최종 항목 을 선정하고자 하였다. 이를 위해 4-6세 일반아동을 대상으로 35개 의 예비 항목으로 구성된 nSRT 검사를 실시하였다.

\section{연구대상}

연구의 대상은 4 세 20 명, 5 세 21 명, 6 세 15 명, 총 56 명의 일반아동 들이었다. 대상자의 선정 기준은 다음과 같다. 첫째, 부모와 교사의 보고에 의해 감각적, 신경학적, 신체적 결함이 없고 인지, 언어적 문 제가 없는 아동, 둘째, 수용-표현어휘력검사(REVT; Kim, Hong, Kim, Jang, \& Lee, 2009) 결과 수용 및 표현어휘 능력이 -1 SD 이상 범위에 속하는 아동, 셋째, 우리말 조음음운평가(U-TAP; Kim \& Shin, 2004) 결과 단어 수준의 자음정확도가 -1 SD 이상의 범위에 속하는 아동들을 대상으로 하였다. 본 연구에 참여한 대상자의 정 보를 Table 1에 제시하였다.

\section{연구절차}

검사는 소음의 영향을 최소화한 분리된 공간에서 아동과 연구 자 일대일로 진행하였다. 검사자는 아동과 마주보고 앉아서 "선생 님이 들려주는 단어를 잘 듣고, $\mathrm{OO}$ 이가 들은 대로 다시 말해주면 돼요.”라고 과제 방법에 대해서 간단하게 설명을 한 후, 2 개의 연습 항목(느쩌히꾸, 끄뻐두)을 이용하여 비단어를 듣고 바로 따라말하 
Table 1. Participants' characteristics in experiment 1

\begin{tabular}{lccc}
\hline \multirow{2}{*}{ Characteristic } & \multicolumn{3}{c}{ Typically developing children (yr) } \\
\cline { 2 - 4 } & $4(\mathrm{~N}=20)$ & $5(\mathrm{~N}=21)$ & $6(\mathrm{~N}=15)$ \\
\hline Sex & & & \\
$\quad$ Male & 6 & 9 & 5 \\
$\quad$ Female & 14 & 12 & 10 \\
Chronological age (mo) & $54.95(3.65)$ & $63.47(2.68)$ & $77.26(4.38)$ \\
REVT & & & \\
Receptive vocabulary score & $74.00(9.54)$ & $76.42(2.68)$ & $91.93(14.04)$ \\
$\quad$ Expressive vocabulary score & $77.80(8.46)$ & $80.33(10.72)$ & $92.06(9.67)$ \\
U-TAP & & & \\
PCC (\%) & $99.06(1.14)$ & $99.33(1.05)$ & $100(.00)$ \\
\hline
\end{tabular}

Values are presented as mean (SD).

REVT= Receptive \& Expressive Vocabulary Test (Kim, Hong, Kim, Jang, \& Lee, 2009); $\mathrm{U}-\mathrm{TAP}=$ Urimal Test of Articulation and Phonology (Kim \& Shin, 2004); PCC= percentage of consonants correct.

는 연습을 실시하였다. Y-연결잭을 이용하여 두 개의 이어폰을 노 트북에 연결하여 검사자도 함께 아동에게 들리는 비단어를 확인하 였다. 아동으로 하여금 한 음절씩 최대한 또박또박 발음할 것을 요 구하였는데, 이는 특히 /ㅎ/가 어중에 위치한 경우 빠르게 발음하면 조음운동의 용이성으로 인해/ㅎ/ 탈락 음운변동이 유도될 가능성 을 최소화하기 위함이었다. 검사자는 아동의 모든 반응을 녹음하 였고, 동시에 현장에서 바로 전사하였다. 검사 직후 녹음된 발화를 들으며 전사 결과를 다시 한 번 점검, 보완하는 과정을 거쳤다. 비단 어 자극어는 한 번만 들려주는 것을 원칙으로 하되, 주변 소음으로 인해 혹은 아동의 부주의로 인해 제대로 듣지 못하였다고 판단된 경우 한 번의 기회를 더 제공하였다.

\section{자료 분석}

앞에서 설명하였던 채점 방법을 이용하여 대상자의 수행력을 인 출 점수와 배열 점수로 구분하여 기록하였다. 인출과 배열 점수에 근거하여 전체 35 개의 예비 항목 가운데 이질적인 항목을 제거하 고 최종 항목에 대해 구인타당도 분석을 실시하였다. SPSS version 20.0 for Window 프로그램으로 56명 일반아동의 인출과 배열 데 이터에 대해 탐색적 요인분석을 실시하여, 공통성이 .40 미만인 비 단어 항목은 제거하였다. 순차적인 절차는 다음과 같다. 첫째, 인출 과 배열 모두에서 공통성이 .40 미만인 항목을 제거하였다. 둘째, 인출에서만 공통성이 .40 미만인 항목을 제거하였다. 셋째, 배열에 서 공통성이 .40 미만인 항목 순으로 제거하였다. 이와 같은 과정을 통해 최종 비단어 항목을 선정하였고, 최종 항목 간 내적일치도를 살펴보기 위해 인출 점수에 대해 Cronbach's alpha 계수를 이용한 내적일치 신뢰도 분석을 실시하였다.
Table 2. Participants' characteristics in experiment 2

\begin{tabular}{lccc}
\hline \multirow{2}{*}{ Characteristic } & \multicolumn{3}{c}{ Typically developing children (yr) } \\
\cline { 2 - 4 } & $4(\mathrm{~N}=19)$ & $5(\mathrm{~N}=14)$ & $6(\mathrm{~N}=12)$ \\
\hline Sex & & & \\
Male & 13 & 5 & 4 \\
$\quad$ Female & $54.78(3.67)$ & $63.40(2.80)$ & $78.40(4.15)$ \\
Chronological age (mo) & & & \\
REVT & $74.21(9.74)$ & $82.71(8.84)$ & $95.50(13.50)$ \\
Receptive vocabulary score & & & \\
Expressive vocabulary score & $77.68(8.66)$ & $85.78(8.45)$ & $95.75(6.82)$ \\
U-TAP & & & $100(.00)$ \\
PCC (\%) & $99.14(1.12)$ & $99.66(.81)$ & \\
\hline
\end{tabular}

Values are presented as mean (SD).

REVT = Receptive \& Expressive Vocabulary Test (Kim, Hong, Kim, Jang, \& Lee, 2009); U-TAP=Urimal Test of Articulation and Phonology (Kim \& Shin, 2004); PCC= percentage of consonants correct.

\section{단어유사성 및 평균 음절빈도 산출}

최종 선정된 비단어 항목의 단어유사성을 알아보기 위해 언어재 활사 또는 언어치료학과 대학원생 81 명을 대상으로 설문조사를 실 시하였다. Google 설문조사 어플리케이션을 이용하여 Likert 5점 평점법 $(1=$ '단어와 매우 유사하지 않음' $2=$ '단어와 유사하지 않 음', 3 = '보통임', $4=$ ='단어와 유사함', $5=$ '단어와 매우 유사함')의 단어유사성 조사를 실시한 후, 모든 비단어 항목에 대해 평균 단어 유사성 정도를 산출하였다. 그리고 비단어 항목의 평균 음절빈도 산출을 위해서는 100만 음절 말뭉치 자료(Kim \& Kang, 1997)를 참고하였다. 각 음절별 음절빈도를 구하여 그 값을 모두 합산한 후 다시 음절수로 나누어, 모든 항목에서 평균 음절빈도를 구하였다.

\section{실험 2: nSRT의 적용}

연구대상

실험 2의 연구대상은 실험 1 의 대상자 가운데 수용·표현어휘력 검사 결과가 $-1 \mathrm{SD}$ 의 경계선에 위치한 아동들을 제외한 나머지 아 동들이었다. nSRT를 적용하여 정상 발달하는 일반아동의 연령별 차이를 관찰하는 것이 목적인 만큼, 언어능력 저하가 의심되는 아 동은 대상자에서 제외하는 것이 타당할 것으로 판단하였기 때문이 다. 실험 2 의 대상 아동은 실험 1 의 대상 아동에서 11 명이 제외되어 4 세 19 명, 5 세, 14 명, 6 세 12 명의 총 45 명이었고, 구체적인 대상자 정 보는 Table 2와 같다.

\section{연구 절차 및 자료 분석}

연구 절차와 채점 방법은 실험 1 과 동일하다. 통계 분석은 실험 1 과 마찬가지로 SPSS version 20.0 for Window 프로그램을 이용하 
였고, 연령별(4-6세) 음절수(3-5음절)와 음운처리 종류(인출, 배열) 에 따른 비단어 따라말하기 수행력에 유의한 차이가 있는지 알아 보기 위해 1 피험자 간-2 피험자 내 혼합설계에 따른 반복측정 분 산분석(repeated measure ANOVA)을 실시하였다.

\section{연구결과}

\section{실험 1: nSRT의 최종 항목}

35 개의 예비 항목에서 최종 비단어 항목을 구성하기 위해 구인 타당도를 검정하였다. 우선, 요인분석을 실시하기 위해 Kaiser-Meyer-Olkin (KMO)과 Bartlett의 구형성 검정을 실시하였다. $\mathrm{KMO}$ 값 이 1 에 가까울수록 요인을 분석하기에 적합하다는 것을 의미한다. 다시 말해, 값이 80 을 상회할 때 관련 변수 간의 연관성 및 적절성 은 높다고 할 수 있는데, 본 연구의 경우 $\mathrm{KMO}$ 값이 .904로, 1 에 가 깝게 나타났다. 다음으로, Bartlett의 구형성은 유의확률이 작을수 록 요인분석이 적합하다고 판단할 수 있다. 검정 결과, 측정변수 간 하나라도 상관관계가 있다는 대립가설이 채택되어 $(p<.001)$, 본 연 구의 비단어 예비 항목 데이터는 요인분석하기에 적합한 것으로 나 타났다. 한편, 예비 항목에 대해 .40 미만의 인출 및 배열의 공통성 을 제거한 후 탐색적 요인분석을 실시한 결과, 요인부하 값. 40 이상 의 비단어 항목(3음절 7개, 4 음절 7개, 5 음절 7개) 21 개가 최종적으 로 선택되었고, 따라서 최종 비단어 항목에 대한 구인타당도가 확 보되었다. 예비 비단어 항목에 대한 요인부하 값과 공통성 값은 Appendix 1에, 최종 선정된 항목은 Appendix 2에 제시하였다. 구 인 타당도가 확보된 최종 비단어 항목에 대해 문항내적일관성신뢰 도(Conbach's alpha)를 측정하였다. 신뢰도의 경우.70 이상이면 신 뢰도가 높다고 판단할 수 있는데, 본 연구의 최종 비단어 항목의 신 뢰도는 3 음절에서 $.803,4$ 음절에서 $.805,5$ 음절에서 .806 , 전체 항목 에서 .914로 매우 높게 나타났다. 따라서 최종 선정된 비단어 항목 들이 매우 동질적이고 강한 신뢰도가 있음을 알 수 있다.

최종항목에 대한 단어유사성 조사 결과, 한 항목 $(/$ 머쿠니 $/=2.06)$ 을 제외한 모든 항목이 2점 이하(단어와 유사하지 않음)에 해당하 였다. 평균 단어유사성은 3음절 1.72점(SD .18), 4음절 1.43점(SD .12), 5음절 1.37점(.67)이었다. 또한 항목들의 평균 음절빈도를 산출 한 결과, 모든 항목은 200 이상이었고, 음절수별 평균값은 3 음절 $1,788.38,4$ 음절 $653.34,5$ 음절 888.71 이었다. 따라서 본 연구의 항 목은 단어유사성은 낮고 음절빈도는 높은 항목들로 이루어졌음을 알 수 있다. 구체적인 단어유사성과 평균 음절빈도 값을 Appendix 2에 제시하였다.

\section{실험 2: 연령 집단 간 음절수 및 음운처리 종류에 따른 수행력 차이}

일반아동의 연령 집단별 인출 및 배열 수행력에 대한 기술통계 는 Table 3 과 같다. 인출과 배열의 총점이 상이하기 때문에, 인출과 배열 수행력 모두 100점 만점으로 환산하여 백분율로 나타낸 수치 이다. 평균적으로 연령이 높아질수록 인출과 배열 수행력이 모두 향상되었고, 모든 연령 집단에서 배열보다 인출 수행력이 더 좋다 는 것을 알 수 있다. 이와 같은 차이가 통계적으로 유의한지 알아본 결과, 집단 간 주효과가 유의하였고 $\left(F_{(2,27)}=6.011, p<.01\right)$, 집단 내 음절수에 대한 주효과 $\left(F_{(1,42)}=27.828, p<.001\right)$, 음운처리 종류에 대한 주효과 $\left(F_{(1,42)}=119.816, p<.001\right)$, 그리고 음절수와 음운처리 종류의 상호작용효과 $\left(F_{(1,42)}=14.990, p<.001\right)$ 또한 유의한 것으로 나타났다. 유의한 결과에 대해 구체적인 차이를 알아보기 위해 각 각 사후검정을 실시하였다. 첫째, 집단 간 주효과에 대한 Scheffe 사 후검정 결과, 4 세와 6 세 집단 간 유의한 차이를 보였으나 $(p<.01), 4$ 세와 5 세 집단 간 차이는 유의하지 않았다 $(p>.05)$. 둘째, 음절수에 대한 주효과에 대해 Bonferroni 사후검정을 실시한 결과, 3 음절과 5 음절 간 $(p<.001), 4$ 음절과 5 음절 간 $(p<.001)$ 유의미한 차이가 있 었으나, 3음절과 4음절 간 차이가 유지하지 않았다( $p>.05)$. 셋째, 음절수와 음운처리 종류에 대한 상호작용효과 분석을 위해, $\mathrm{COM}$ PARE 하위명령어를 입력한 Syntax를 실행시켜 사후검정을 실시 하였다. 그 결과 인출 점수의 경우 3 음절과 4 음절 $(p<.05), 4$ 음절과 5 음절 $(p<.001), 3$ 음절과 5 음절 $(p<.001)$ 모두에서 유의한 차이가 있었던 반면, 배열 점수의 경우 3 음절과 5 음절 $(p<.001), 4$ 음절과 5 음절 $(p<.001)$ 간에는 유의한 차이를 보였으나 3 음절과 4 음절 간 차이는 통계적으로 유의미하지 않았다.

Table 3. Descriptive analysis on phonological retrieval and sequencing scores of nSRT according to the number of phonemes by age groups (unit: \%)

\begin{tabular}{llll}
\hline & 3 syllables & 4 syllables & 5 syllables \\
\hline Phonological retrieval (yr) & & & \\
4 & $64.84(9.19)$ & $62.05(8.95)$ & $51.31(11.32)$ \\
5 & $68.13(9.72)$ & $65.32(9.67)$ & $60.21(8.17)$ \\
6 & $75.00(6.50)$ & $73.87(7.17)$ & $68.16(7.79)$ \\
Total & $69.32(4.23)$ & $67.08(1.05)$ & $61.89(1.58)$ \\
Phonological sequencing (yr) & & & \\
4 & $57.86(11.47)$ & $51.64(13.46)$ & $40.39(18.17)$ \\
5 & $61.53(12.32)$ & $55.95(13.14)$ & $44.67(13.96)$ \\
6 & $66.45(19.04)$ & $67.62(6.62)$ & $56.29(8.75)$ \\
Total & $61.95(3.38)$ & $58.40(3.15)$ & $47.12(3.85)$ \\
\hline
\end{tabular}

Values are presented as mean (SD). nSRT = nonsense Syllable Repetition Test. 


\section{논의 및 결론}

본 연구에서는 nSRT의 예비 항목을 제작한 후 탐색적 요인분석 실시하여, 3음절, 4 음절, 5 음절 각각 7 개씩, 총 21 개의 항목으로 구 성된 새로운 nSRT를 개발하였다(Appendix 2). 문항내적일치신뢰 도(Cronbach's alpha) 분석 결과, 일치신뢰도가 각 음절수에서는 모두 .800 이상, 전체 항목에서는 .914로, 항목 간 높은 신뢰도를 나 타내었다. 또한 단어유사성 조사 결과 평균 단어유사성이 3음절, 4 음절, 5 음절 각각 1.72 점, 1.43 점, 1.37 점에 해당하였고, 평균 음절빈 도 산출 결과 평균값이 3 음절, 4 음절, 5 음절 각각 $1,788.38,653.34$, 888.71로 측정되었다. 따라서 본 연구에서 개발된 nSRT는 높은 타 당도와 신뢰도를 갖추었고, 연구자의 의도대로 단어유사성이 낮은 항목들로 구성되었음을 확인하였다. 또한 평균적으로 빈도가 높은 음절들로 구성되었기 때문에, 대상자의 수행력 저하가 자극어의 음운적 특성으로 인해 초래되었을 가능성을 최소화하였다.

개발된 nSRT를 이용하여 4-6세 일반아동들을 대상으로 검사를 실시한 결과, 연령이 증가할수록 nSRT 수행력이 유의하게 향상되 는 것을 알 수 있었다. 이에 본 연구에서 개발한 nSRT는 연령에 따 른 발달 양상을 민감하게 평가할 수 있는 도구라 할 수 있다. 또한 모든 연령의 아동들이 음절수가 길어짐에 따라 기억 용량의 부담으 로 인해 유의하게 수행력이 저하되는 특성을 보였다. 이 또한 음절 수에 따른 수행 결과의 차이를 민감하게 나타내는 것으로, 본 연구 에서 제작된 3-5음절 자극어는 대상자의 음운처리능력을 민감하 게 평가하는 항목이라고 할 수 있다. 따라서 음절수별 대상자의 수 행 차이를 비교 분석함으로써 대상자의 음운처리능력을 보다 심층 적으로 평가할 수 있을 것으로 기대한다. 마지막으로 대상자들은 연령에 상관없이 인출보다 배열에서 수행의 정확도가 유의하게 떨 어졌고, 인출 점수는 3-5음절 간 차이가 모두 유의하였던 반면, 배 열 점수에서는 3 음절과 4 음절 간 차이가 유의하지 않았다. 인출과 배열에 대해서는 보다 깊이 있는 논의가 필요할 것으로 보이는데, 그 이유는 본 연구가 비단어 따라말하기 과제에서 배열 수행력을 독립적으로 분석한 최초의 시도이기 때문이다.

본 연구의 가장 큰 의의 중 하나는 nSRT에서 음운인출과 음운배 열 능력을 구분하여 살펴보고자 한 것, 그리고 그에 대한 점수체계 를 확립한 것이라 할 수 있다. 서론에서 언급하였듯이 일련의 말소 리 정보들을 성공적으로 산출하기 위해서는 음운 자체를 잘 인출 하고 음운 간 일련의 순서들을 순차적으로 배열할 수 있어야 한다. 따라서 배열 또한 인출만큼 중요한 능력임에도 불구하고 이제까지 음운처리능력을 평가하였던 많은 검사들은 이를 간과하여 왔다. 말산출처리과정에 관한 심리언어학적 모델에 근거할 때 음운부호
화는 어휘소(lexeme)에 포함된 각각의 음소들을 활성화시킨 후 그 것을 순차적으로 배열하는 과정이다(Dell, Chang, \& Griffin, 1999). 이처럼 배열은 인출된 음소 간 순차적 관계를 형성하는 것으 로, 배열을 하기 위해서는 인출을 전제로 한다. 배열의 경우 시작점 과 끝점의 두 기준점에서 점수를 획득할 기회를 주었음에도 불구 하고, 배열 수행력이 인출 수행력보다 유의하게 떨어졌던 본 연구 결과는 이러한 말처리과정의 순서를 반영한 것으로 보인다. 다시 말해 인출을 잘 하더라도 배열 수행력은 떨어질 수 있지만, 인출 수 행력이 뒷받침되지 않고는 배열을 잘 할 수 없다. 이러한 경향은 음 절수에 따른 차이에서도 다시 한 번 확인할 수 있었는데, 배열의 경 우 인출과 달리 3 음절 비단어부터 어려움을 보이는 아동들이 상당 수 있어 3 음절과 4 음절 간 차이가 유의하지 않았다.

이와 같은 배열 수행력의 결과는 음운오류가 음운지식, 음운인 출 등의 어려움 외에도 배열의 문제로도 나타날 수 있음을 시사한 다. 더 구체적으로는 말소리장애 집단 가운데 말소리 결함이 음운 배열의 어려움과 관련이 있는 하위집단을 고려해 볼 수 있다. 이와 관련하여 Dodd (1994)와 Crosbie, Holm과 Dodd (2005)는 그들의 말소리장애 하위집단 중 네 번째 집단인 비일관적 음운장애 집단 의 특성을 음운의 배열처리 결함과 관련하여 설명한 바 있다. 말소 리 산출에 변이성을 보이는 비일관적 음운장애 집단의 경우 음운 계획(phonological planning)의 결함과 관련이 있는데, 이때 음운 계획이란 음소의 선택(phoneme selection)과 배열(sequencing)의 처리과정을 의미한다고 언급하였다. 음소의 선택은 본 연구의 음운 인출과 동일한 것을 의미하는 것이며, 따라서 음운인출과 배열의 두 가지 측면 모두에 어려움이 있으면 그 결과로 특이한 말소리 오 류를 비일관적으로 나타내는 양상을 보일 수 있다. 그뿐만 아니라 아동기 말실행증의 경우에도 운동통제능력의 손상과 더불어 음운 계획과정에서의 결함이 보고된 바 있는데(Panagos \& Bobkoff, 1984), 이 또한 음운배열의 어려움과 연관 지어 설명해 볼 수 있을 것이다.

본 연구는 일반아동만을 대상으로 하였기 때문에 대상자 간 전 반적인 수행 양상이 크게 다르지 않았다. 그러나 추후 말소리장애 를 포함한 의사소통장애 아동들과 일반아동들의 수행을 비교해 보면 이보다 다양한 양상들이 나타날 것으로 예측된다. 아마도 대 상자들이 보이는 수행 양상에 따라 인출 수행력은 좋으나 배열 수 행력이 낮은 집단, 인출 수행력과 배열 수행력이 모두 낮은 집단, 인 출 수행력과 배열 수행력이 모두 낮지만 배열 수행력이 현저히 떨어 지는 집단 등 다양한 하위집단으로 구분될 수 있을 것이다. 그러나 이러한 연구자들의 가설이 보다 설득력을 얻기 위해서는, 의사소 통장애 아동의 nSRT 수행력에 대한 보다 객관적이고 심층적인 추 
후 연구가 요구된다.

본 연구에서는 nSRT 과제에 대해 그 타당성과 신뢰성을 입증한 후, 그것을 일반아동에게 적용하여 임상적 및 학문적으로 의미 있 는 결과를 도출하였다. 무엇보다 어휘지식의 영향을 최대한 통제하 여 기존 비단어 따라말하기 과제와 차별적인 항목을 개발하였다 는 점, 그리고 배열 점수를 도입함으로써 보다 다각적 측면에서 음 운처리능력을 평가하고자 하였다는 점에서 본 연구는 의의가 있을 것이다. 이와 같은 의의에도 불구하고 본 연구는 다음과 같은 제한 점 또한 가지고 있다. 첫째, 어휘지식을 최대한 통제하기 위해 엄격 한 기준을 적용하여 기준에 위반되는 항목들은 모두 제외하였다. 그 결과 최종적으로 자극어에 사용된 일음절은 평음 11 개, 경음 13 개, 격음 4 개로 구성된 일음절로, 경음이 가장 높은 비율을 차지하 였다. 자극어에 포함된 자음의 발성유형적 특성으로 인해 nSRT 과 제 수행 시 동반되는 대상자의 청지각적 및 운동적 수행이 영향을 받았을 가능성을 배제할 수 없다. 따라서 이에 대해서는 추후 연구 가 필요할 것이다. 둘째, 마찬가지로 어휘지식을 통제하기 위해 엄 격한 기준을 적용하다보니 최종적으로 자극어에 사용된 일음절 수가 다소 제한적이었다. 이는 의도한 비단어 자극어 제작을 위해 불가피한 것이었으나, 제한된 음절의 반복적 노출로 인해 해당 음 절들에 대해 오히려 친숙도가 높아졌을 가능성, 즉 학습효과가 초 래되었을 가능성도 배제할 수 없다. 따라서 이에 대해서도 추후 살 펴볼 필요가 있을 것이다.

연구자들은 본 연구를 바탕으로 인출과 배열 점수의 자동 채점 이 가능한 전산화 nSRT검사를 제작 중에 있다. 앞으로 다차원적 음운처리능력에 대해 신뢰할 수 있는 결과를 간편하게 얻을 수 있 는 유용한 검사 프로그램을 제공할 수 있기를 기대한다.

\section{REFERENCES}

Adams, A. M., \& Gathercole, S. E. (2000). Limitations in working memory: implications for language development. International Journal of Language and Communication Disorders, 35, 95-116.

Baddeley, A., Gathercole, S., \& Papago, C. (1998). The phonological loop as a language learning device. Psychological Review, 105, 158-173.

Bishop, D. V. (2002). Motor immaturity and specific speech and language impairment: evidence for a common genetic basis. American Journal of Medical Genetics, 114, 56-63.

Bishop, D. V., Adams, C. V., \& Norbury, C. F. (2004). Using nonword repetition task to distinguish genetic and environment influences on early literacy development. American Journal of Medical Genetics, 129, 94-96.
Boerma, T., Chiat, S., Leseman, P., Timmermeister, M., Wijnen, F., \& Blom, E. (2015). A quasi-universal nonword repetition task as a diagnostic tool for bilingual children learning Dutch as a second language. Journal of Speech, Language and Hearing Research, 58, 1747-1760.

Campbell, T., Dollaghan, C., Needleman, H., \& Janosky, J. (1997). Reducing bias in language assessment: processing-dependent measures. Journal of Speech, Language, and Hearing Research, 40, 519-525.

Crosbie, S., Holm, A., \& Dodd, B. (2005). Intervention for children with severe speech disorder: a comparison of two approaches. International Journal of Language and Communication Disorders, 40, 467-491.

Dell, G. S., Chang, F., \& Griffin, Z. M. (1999). Connectionist models of language production: lexical access and grammatical encoding. Cognitive Sciences, 23, 517-542.

Dodd, B. (1994). Differential diagnosis and treatment of children with speech disorders. London: Whurr.

Dollaghan, C., \& Campbell, T. (1998). Nonword repetition and child language impairment. Journal of Speech, Language, and Hearing Research, 41, 11361146.

Fischer-Baum, S., \& McCloskey, M. (2015). Representation of item position in immediate serial recall: evidence from intrusion errors. Journal of Experimental Psychology: Learning, Memory, and Cognition, 41, 1426-1446.

Gupta, P. (2005). Primacy and recency in nonword repetition. Memory, 13, 318-324.

Gupta, P., Lipinski, J., Abbs, B., \& Lin, P. H. (2005). Serial position effects in nonword repetition. Journal of Memory and Language, 53, 141-162.

Hwang, J., K., \& Ha, S. H. (2010). Nonword repetitions of 2- to 5-year-old typically developing children. Korean Journal of Communication \& Disorders, $15,561-571$.

Hwang, J. H. (2018). Influence of retrieval distractors and array distractors on phonological encoding performance in adults. Proceedings of the 2018 Spring Conference of Korean Society of Speech Science, 55.

Hwang, M. A. (2015). Nonword repetition of typically developing children. Communication Sciences \& Disorders, 20, 374-385.

Jo, N. H. (2002). The frequency of modern Korean words. Seoul: National Institute of the Korean Language.

Jung, S. M., \& Ha, S. H. (2017). The relationship among nonword repetition, age, vocabulary and articulation ability. Communication Sciences \& Disorders, 22, 14-24.

Kang, E. H., \& Kang, D. O. (2016). Characteristics of non-word repetition and sentence repetition performance of preschool children with specific 
language impairment. Journal of Special Education \& Rehabilitation Science, 55, 559-573.

Kim, H. K., \& Kang, B. M. (1997). Frequency analysis of the use of Hangul. Seoul: Korea University, Research Institute of Korea Studies.

Kim, N. Y., \& Ha, J. W. (2014). Phonological representations in children with articulation and phonological disorders. Communication Sciences \& Disorders, 19, 226-237.

Kim, N. Y., \& Ha, J. W. (2018). The effect of lexical bias on phoneme sequencing performance of normal age groups. Proceedings of the 2018 Conference of Korean Speech-Language and Hearing Association, 183-186.

Kim, Y. T., \& Shin, M. J. (2004). Urimal test of articulation and phonology (UTAP). Seoul: Hakjisa.

Kim, Y. T., Hong, G. H., Kim, K. H., Jang, H. S., \& Lee, J. Y. (2009). Receptive \& expressive vocabulary test (REVT). Seoul: Seoul Community Rehabilitation Center.

Lee, E. J., \& Sim, H. S. (2003). Phonological memory in the nonword repetition of children: a comparison of functional phonologically disordered and normal children. Korean Journal of Communication \& Disorders, 8 , 127-145.

Lee, H. J. (2010). The influences of number of syllables and wordlikeness on 3to 5-year-old Korean-English bilingual children's nonword repetition (Master's thesis). Ewha Womans University, Seoul, Korea.

Lee, S. J., Ha, J. W., Koo, M. M., Hwang, Y. M., \& Pyun, S. B. (2016). Delayed non-word repetition according to rehearsal conditions in 6- to 7-year-old children. Communication Sciences \& Disorders, 21, 69-83.

Mackay, D. G., \& James, L. E. (2004). Sequencing, speech production, and selective effects of aging on phonological and morphological speech errors. Psychology and Aging, 19, 93-107.

Oh, D. Y., \& Yim, D. S. (2013). Non-word repetition and sentence repetition performance in 2-3 years old late talkers and normal children. Communication Sciences \& Disorders, 18, 277-287.

Paik, K. A., \& Hwang, B. M. (2011). Phonological discrimination ability and phonological working memory of typically developing children and children with specific language impairments. Phonetics and Speech Sciences, 3, 95-102.

Panagos, J. M., \& Bobkoff, K. (1984). Beliefs about developmental apraxia of speech. Australian Journal of Human Communication Disorders, 12, 39-53.

Ryu, E. J., \& Ha, J. W. (2016). The effect of vocal rehearsal on retrieval of new phonological representations in children with and without specific language impairment. Communication Sciences \& Disorders, 21, 605-616.

Shriberg, L. D., Lewis, B. A., Tomblin, J. B., McSweeny, J. L., Karlsson, H. B., \& Scheer, A. R. (2005). Toward diagnostic and phenotype markers for genetically transmitted speech delay. Journal of Speech, Language, and Hearing Research, 48, 834-852.

Shriberg, L. D., Lohmeier, H. L., Campbell, T. F., Dollaghan, C. A., Green, J. R., \& Moore, C. A. (2009). A nonword repetition task for speakers with misarticulations: the Syllable Repetition Task (SRT). Journal of Speech, Language, and Hearing Research, 52, 1189-1212. 
Eun Joo Ryu, et al. • Nonsense Syllable Repetition Test

Appendix 1. The communality and factor loading of nonword items in sequencing and retrieval scores

\begin{tabular}{|c|c|c|}
\hline \multirow{2}{*}{ 항목 } & 공통성 & \multirow{2}{*}{ 요인부하값 } \\
\hline & 인출 & \\
\hline 두머꼬즈 & .736 & .820 \\
\hline 뿌머크 & .533 & .721 \\
\hline 므쩌뽀니 & .536 & .663 \\
\hline 므니뻐쿠꼬 & .630 & .660 \\
\hline 쁘쿠네 & .602 & .633 \\
\hline 즈두버히꼬 & .470 & .496 \\
\hline 삐머트 & .600 & .755 \\
\hline 머삐꾸쪼 & .587 & .725 \\
\hline 그쪼버 & .581 & .713 \\
\hline 트니뽀 & .637 & .676 \\
\hline 머쿠니 & .506 & .542 \\
\hline 꼬니뜨 & .458 & .491 \\
\hline 쿠버쪼느 & .371 & .486 \\
\hline 두쪼너끄 & .461 & .458 \\
\hline 쯔너뽀두히 & .554 & .707 \\
\hline 버히쪼므 & .605 & .675 \\
\hline 삐드머쭈네 & .582 & .664 \\
\hline 그뻐니두꼬 & .449 & .663 \\
\hline 뽀쩌므히네 & .627 & .601 \\
\hline 드쿠머쪼삐 & .501 & .481 \\
\hline \multirow[t]{2}{*}{ 쩌드꾸니 } & .472 & .424 \\
\hline & 배열 & \\
\hline 뻐히쪼므 & .617 & .754 \\
\hline 즈두버히꼬 & .633 & .753 \\
\hline 쯔너뽀두히 & .622 & .706 \\
\hline 드쿠머쪼삐 & .638 & .659 \\
\hline 그뻐니두꼬 & .417 & .618 \\
\hline 뽀쩌므히네 & .420 & .571 \\
\hline 삐드머쭈네 & .542 & .563 \\
\hline 므니뻐쿠꼬 & .404 & .544 \\
\hline 쩌드꾸니 & .434 & .475 \\
\hline 꼬니뜨 & .596 & .750 \\
\hline 머쿠니 & .676 & .745 \\
\hline 쁘쿠네 & .588 & .696 \\
\hline 두쪼너끄 & .557 & .574 \\
\hline 머삐꾸쪼 & .449 & .539 \\
\hline 두머꼬즈 & .513 & .523 \\
\hline 트니뽀 & .584 & .521 \\
\hline 뿌머크 & .397 & .476 \\
\hline 그쪼버 & .753 & .854 \\
\hline 므쩌뽀니 & .446 & .601 \\
\hline 삐머트 & .465 & .522 \\
\hline 쿠버쪼느 & .398 & .478 \\
\hline
\end{tabular}


Appendix 2. Average of word similarity, syllable frequency of nonword items

\begin{tabular}{|c|c|c|c|}
\hline & 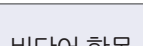 & 단어유사성 & 평균 음절빈도 \\
\hline & 디닌기 잉ㄱㄱㄱ & 평균(표준편차) & 평균(표준편차) \\
\hline 3음절 & 삐머트 & $1.62(.93)$ & 642.67 \\
\hline & 꼬니뜨 & $1.51(.82)$ & $2,101.71$ \\
\hline & 쁘쿠네 & $1.62(.87)$ & 304.48 \\
\hline & 트니뽀 & $1.65(.99)$ & $2,389.64$ \\
\hline & 머쿠니 & $2.06(1.08)$ & $2,340.38$ \\
\hline & 그쪼버 & $1.72(.94)$ & $4,168.01$ \\
\hline & 뿌머크 & $1.84(1.04)$ & 571.78 \\
\hline & 전체 & $1.72(.18)$ & $1,788.38(1,379.71)$ \\
\hline 4음절 & 두머꼬즈 & $1.63(.79)$ & 790.73 \\
\hline & 므쩌뽀니 & $1.47(.79)$ & 310.11 \\
\hline & 뻐히쪼므 & $1.26(.59)$ & 561.74 \\
\hline & 쿠버쪼느 & $1.30(.60)$ & $1,783.38$ \\
\hline & 쩌드꾸니 & $1.48(.79)$ & $1,883.88$ \\
\hline & 두쪼너끄 & $1.46(.84)$ & 696.38 \\
\hline & 머삐꾸쪼 & $1.42(.77)$ & 354.15 \\
\hline & 전체 & $1.43(.12)$ & $911.48(653.34)$ \\
\hline 5음절 & 므니뻐쿠꼬 & $1.31(.58)$ & 277.06 \\
\hline & 쯔너뽀두히 & $1.26(.49)$ & 929.57 \\
\hline & 삐드머쭈네 & $1.57(.89)$ & 583.17 \\
\hline & 즈두버히꼬 & $1.30(.58)$ & $1,042.65$ \\
\hline & 뽀쩌므히네 & $1.43(.79)$ & 608.65 \\
\hline & 드쿠머쪼삐 & $1.37(.68)$ & 468.88 \\
\hline & 그뻐니두꼬 & $1.35(.67)$ & $2,898.87$ \\
\hline & 전체 & $1.37(.67)$ & 972.69 (888.71) \\
\hline
\end{tabular}




\section{국문초록}

\section{음운 인출 및 배열 처리능력 평가를 위한 무의미 음절 따라말하기 검사의 개발 및 적용 류은주'(학생, 제1저자) · 하지완'(교수, 교신저자) \\ ${ }^{1}$ 대구대학교 일반대학원 재활과학과 언어치료전공, ${ }^{2}$ 대구대학교 언어치료학과}

배경 및 목적: 본 연구에서는 타당도와 신뢰도를 검증한 무의미 음절 따라말하기 검사(nSRT)를 개발한 후, 이를 학령전기 일반아동들 에게 적용하여 대상자들의 인출능력과 배열능력을 연령 간 비교해 보고자 하였다. 방법: 3-5음절로 구성된 nSRT 예비 항목에 대해 탐 색적 요인분석을 통해 최종 nSRT 항목을 도출하였고, 이에 대해 Cronbach's alpha 문항내적일관성 신뢰도 분석, 단어유사성 조사, 평 균음절빈도 산출을 실시하였다. 이후 4-6세 일반아동을 대상으로 nSRT 검사를 실시하였고, 연령 집단 간 수행 차이를 인출과 배열 점 수, 그리고 음절수로 나누어 살펴보았다. 결과: 3 음절어 7 개, 4 음절어 7 개, 5 음절어 7 개로 구성된 최종 항목이 도출되었다. 전체 항목의 내적일치 신뢰도는 .914로 매우 높았고, 모든 비단어 항목들은 단어유사성은 낮고 평균음절빈도는 높은 것으로 확인되었다. 연령이 증 가할수록 nSRT 수행력은 유의하게 향상되었고, 항목의 길이가 길수록, 그리고 인출보다 배열에서 유의하게 어려움을 보였다. 또한 음 절수에 따라 인출과 배열 점수 양상에 차이가 있는 것으로 나타났다. 논의 및 결론: 본 연구는 타당도와 신뢰도를 갖춘 nSRT 과제를 개 발하고 인출과 배열 점수체계를 확립하였다는 점에서 의의가 있다.

핵심어: 무의미 음절 따라말하기, 음운 배열, 음운 인출, 타당도, 신뢰도

본 논문은 2017년 정부(교육부)의 재원으로 한국연구재단의 지원을 받아 수행된 연구임(NRF-2017R1C1B1010913).

\section{참고문헌}

강은희, 강대옥(2016). 학령 전 단순언어장애 아동의 비단어따라말하기와 문장따라말하기 수행능력 특성. 특수교육재활과학연구, 55, 559-573.

김나연, 하지완(2014). 조음음운장애아동과 일반 아동의 음운표상의 질과 음운표상 부호화 능력 비교. Communication Sciences \& Disorders, 19,

226-237.

김남윤, 하지완(2018). 어휘편향화가 정상 성인의 연령 집단 간음소배열 수행력에 미치는 영향 2018 한국언어치료학회 학술대회 발표논문집, 183-186. 김영태, 신문자(2004). 우리말 조음·음운평가(U-TAP). 서울: 학지사.

김영태, 홍경훈, 김경희, 장혜성, 이주연(2009). 수용·표현어휘력검사(REVT). 서울: 서울장애인종합복지관.

김흥규, 강범모(1997). 한글 사용빈도의 분석. 서울: 고려대학교 민족문화연구소.

류은주, 하지완(2016). 외현적 시연이 단순언어장애아동과 일반아동의 새로운 음운표상인출 수행력에 미치는 영향. Communication Sciences \&

Disorders, 21, 605-616.

백경아, 황보명(2011). 일반 아동과 단순언어장애 아동의 음운변별능력 및 음운작업기억 특성. 말소리와음성과학, 3, 95-102.

오다연, 임동선(2013). 2-3세 말 늦은 아동과 정상 아동의 비단어 따라말하기와 문장 따라말하기 수행 능력. Communication Sciences \& Disorders,

$18,277-287$

이석정, 하지완, 구민모, 황유미, 편성범(2016). 6, 7세 아동의 시연조건에 따른 지연 비단어따라말하기 능력 비교. Communication Sciences \& Disorders, 21, 69-83.

이은주, 심현섭(2003). 무의미 음절 따라말하기를 통한 단순조음음운장애아동과 정상아동의 음운기억 수행능력 비교연구. 언어청각장애연구, 8 , 127-145.

이현정(2010). 음절길이와 단어유사성이 3 5세 한국어-영어 이중언어아동의 비단어 따라말하기 수행에 미치는 영향. 이화여자대학교 대학원 석사 학위 청구논문.

정소미, 하승희(2017). 비단어따라말하기와 연령, 어휘 및 조음능력과의 관계. Communication Sciences \& Disorders, 22, 14-27.

조남호(2002). 현대 한국어사용 빈도. 서울: 국립국어연구원.

황민아(2015). 일반 아동의 비단어 따라말하기. Communication Sciences \& Disorders, 20, 374-385.

황지혜(2018). 인출 방해자극과 배열 방해자극이 정상 성인의 음운부호화 수행에 미치는 영향. 2018 한국음성학회 봄 학술대회 발표논문집, 55.

황진경, 하승희(2010). 2-5세 일반 아동의 무의미단어 따라말하기. 언어청각장애연구, 15, 561-571. 